\title{
Kinetic and Enhancement of Biogas Production for The Purpose of Renewable Fuel Generation by Co-digestion of Cow Manure and Corn Straw in A Pilot Scale CSTR System
}

\author{
Jabraeil Taghinazhad*a, Reza Abdib, and Mehrdad Adlc \\ a PhD Candidate, Biosystem Engineering, University of Tabriz, Tabriz, Iran \\ ${ }^{b}$ Department of Biosystem Engineering, University of Tabriz, Tabriz, Iran \\ ${ }^{c}$ Materials and Energy Research Center (MERC), Karaj, Iran
}

\begin{abstract}
Biogas production from anaerobic co-digestion of cow manure (CM) and corn straw residue (CSR) were experimentally investigated using a completely stirred tank reactor (CSTR) under semi- continuously feeding circumstance at mesophilic $\left(35^{\circ} \mathrm{C} \pm 2\right)$ temperature. The pilot-scale digester with $180 \mathrm{~L}$ in volume was employed under experimental protocol to examine the effect of the change in organic loading rate on efficiency of biogas production and to report on its steady-state performance. An average organic loading rates of 2 and $3 \mathrm{~kg} \mathrm{VS} .\left(\mathrm{m}^{-3} \cdot \mathrm{d}^{-1}\right)$ and a hydraulic retention time (HRT) of 25 days was examined with respect to two different CM to CSR mixing ratios of 100:0, 75:25 and 50:50, respectively. The results showed both organic loading rates at co-digestion of $\mathrm{CM}+\mathrm{CSR}$ gave better methane yields than single digestion of cow manure. The biogas production efficiency was obtained $0.242,0.204,0.3110 .296,259.5$ and $235 \mathrm{~m}^{3}$.(kg VS input)-1 for 2 and $3 \mathrm{~kg} \mathrm{VS}^{-}\left(\mathrm{m}^{-3} . \mathrm{d}^{-1}\right)$ at CM to CSR mixing ratios of 100:0 , 75:25 and 50:50, respectively. The reactor showed stable performance with VS reduction between 55$74 \%$ during different runs. With increment of loading rate, the VS degradation and biogas yield decreased. Modified Gompertz and logistic plot equation was employed to model the methane production at different organic loading rates and substrate concentrations. The equations gave a good approximation of the maximum methane production $\left(\mathrm{r}_{\mathrm{m}}\right)$ and the methane yield potential $(\mathrm{P})$ with correlation coefficient $\left(\mathrm{R}^{2}\right)$ over 0.99 .
\end{abstract}

Keywords: Biogas; cow manure; corn straw; Kinetic; semi-continuously

Article History: Received Oct $25^{\text {th }}$ 2016; Received in revised form Dec 19 ${ }^{\text {th }}$ 2016; Accepted $2^{\text {nd }}$ January 2017; Available online

How to Cite This Article: Taghinazhad. J., Abdi, R. and Adl, M. (2017). Kinetic and Enhancement of Biogas Production for the purpose of renewable fuel generation by Co-digestion of Cow Manure and Corn Straw in a Pilot Scale CSTR System. Int Journal of Renewable Energy Development, 6(1),37-44

http://dx.doi.org/10.14710/ ijred.6.1.37-44

\section{Introduction}

One of the renewable energy sources is biogas for fossil fuel, which is made from innocuous, safe and biodegradable in the environment such as municipal waste, industrial waste and agricultural, animal and domestic wastes (Omer et al., 2002). Anaerobic digestion (AD) is decomposition of organic matter such as manure, crop residues in the absence of oxygen by concerted action of different groups of anaerobic bacteria. The $\mathrm{AD}$ process that is an important energy source produces biogas that the main component composed of methane $\left(\mathrm{CH}_{4}\right)$, and carbon dioxide $\left(\mathrm{CO}_{2}\right)$ which can be consumed as an energy source. Biogas can be can be directly burned in a combined and heat power unit for the generation of heat and electricity (Ray et al., 2016; Song et al., 2012).

\footnotetext{
*Corresponding author: taghinazhad55@gmail.com
}

Biogas produced from biogenic material, the feedstock used for biogas production constitute of mono substrate or co-digestion of mixture of several organic materials depending on the reactor technology, availability of feedstock, economic consideration etc., is a type of biofuel (Themelis, \& Ulloa, 2007). AD of organic materials to biogas is characterized by the four major steps: hydrolysis, acidogensis, acetogenesis and methanogenesis consecutively. All the mentioned steps run almost at the same time in a biogas reactor. Nearly seventy percent of methane from biogas reactors fed with cattle manure is derived from acetate (Umar et al., 2013; Zhang \& Zhang, 1999). The quantity and quality of biogas depend on characteristics of feedstock as well as process conditions.

Anaerobic fermentation of animal slurry for biogas generation is commonly tested in continuously stirred 
Citation: Taghinazhad. J., Abdi, R. and Adl, M. (2017). Kinetic and Enhancement of Biogas Production for the purpose of renewable fuel generation by Co-digestion of Cow Manure and Corn Straw in a Pilot Scale CSTR System. Int Journal of Renewable Energy Development, 6(1),39-44, doi.org/10.14710/ijred.6.1.39-44

$P$ a g e $\mid 38$

tank reactor (CSTR) and sporadically in plug-flow reactor (Wilkie \& Evans, 2010). In a biogas process with a typical hydraulic retention time (HRT) of 15-30 days, $50-70 \%$ of organic matter is transformed into biogas with an average methane yield of $0.20-0.25 \mathrm{~m}^{3}$ per $\mathrm{kg}$ of added volatile solids (Hartmann et al., 2003). In a study, Boe (2006) indicated that serial digestion, with volume distributions ratio of $90: 10$ or $80: 20$ between the two methanogensis reactors, improved biogas production by $11 \%$ compared to an ordinary one-step CSTR process. In addition, modeling results from this study established that the longer of hydraulic retention time in the post-reactor (second digester of serial process), the higher the methane production of the overall serial digestion (Boe, \& Batstone, 2005).

Agricultural segment provides numerous biomass residues, and it has diversely been estimated that these wasted materials can account for over 30\% of global agricultural productivity(Oliveira, \& Franca, 2009). Corn straw residues that are produced from this part, containing husk, stover, and cob, are lignocellulosic biomass that has been commonly used as one of the conventional substrates for biogas production plants. With the high content of cellulose and hemicelluloses, corn straw residues are considered to be a suitable feedstock for the biogas production. Lignocelluloses are mainly consisting of cellulose, hemicelluloses, lignin, and extractives (Karimi et al., 2013). Mixing organic matters by two or further substrates, which is commonly known as co-digestion, may give a synergistic result that can effect in the higher biogas production (Deublein \& Steinhauser, 2011).

This operation amends the biogas efficiency and methane content in during digestion process and heavily dependent on the organic loading rate (OLR) of co-substrates to the fermentation process. The most popular utilization of co-digestion can be established in agricultural biogas plants by application a fundamental substrate such as animal manure and by adding a little amount of extra substrates (Pesta, 2007). Furthermore, in anaerobic fermentation process, the organic loading rate (OLR) is a main parameter because it illustrates the amount of volatile solids to be fed into the reactor each day (Mattocks, 1984). Other OLR affects the stability of the anaerobic digestion process and biogas production rate by preparing digestible substrates for the population growth of microorganisms (Taricska et al., 2009). Volatile solids indicate that portion of the organic-material solids that can be digested, while the remaining of the solids is fixed. The actual loading rate depends on the kinds of wastes fed into the reactor (Pesta, 2007). Thus, it is a main parameter implying how much organic dry matter (DM) can be fed in reactor per unit of volume and time, and relates to the time that the biomass is retained within the reactor (Lichtman, 1983). Increase in biogas or methane production has been reported from co-digesting cow manure or animal wastes with crop residues since wheat straw, rice straw, sugarcane stalk, maize stalks, cotton stalks, onion waste, Potato Pulp and oil palm fronds (Somayaji \& Khanna, 1994; Sharma, 2002; Karellas et al., 2010;Tong et al., 2013; SanaeiMoghadam et al., 2014; Zhang, et al., 2014).

The lignocellulosic of biomass is rich in carbon, and thus it is important that such material be co-digested simultaneously with materials rich in nitrogen in order to obtain a suitable balance of nutrient, good efficiency, and stability in an anaerobic digester (Jagadabhi et al., 2008 ; Deublein \& Steinhauser, 2011). In a previous study consisted of batch assays, co-digestion of steamexploded Salix and manure led to steady state methane production and more upper compared to single reactor of those substrates. Maximum methane production were produced at $\mathrm{C} / \mathrm{N}$ ratios of $35-40$, which corresponded to about 30-40\% VS from Salix in the codigestion (Estevez et al., 2012).

Many researchers have studied the reaction kinetics of biogas production and developed kinetic models for evaluating the anaerobic digestion process (Zhu et al., 2009; Maamri \& Amrani, 2014; Latinwo \& Agarry, 2015). Moreover, cumulating of biogas could be simulated by logistic and modified Gompertz as well as exponential rise to maximum equations which were universally employed for the simulation of biogas, methane and hydrogen production (Wang \& Wan 2009; Altas, 2009). For example Lo and co-workers reported that the biogas production rates of municipal solid waste (MSW) were increased by applying suitable dose of fly ashes (FA/MSW $=20$ and 10 g.L $\mathrm{L}^{-1}$ ) and bottom ashes (BA/MSW=100 g. $\mathrm{L}^{-1}$ ) compared to control. Equation of modified Gompertz indicates higher correlation of biogas and methane accumulation than exponential rise to maximum model for every digesters(Lo et al.,2010).

The objective of this study was to determine the effect of OLRs and substrate mixing ratio as co-digested in the form of cow manure/corn straw residue as well as acquiring kinetic models for biogas production by a completely stirred tank reactor (CSTR) under semicontinuous feeding in pilot scale at mesophilic conditions. In addition, specific cumulative biogas production was simulated using exponential rise to maximum, logistic growth model and modified Gompertz models, respectively.

\section{Materials and Methods}

\subsection{Substrates and Inoculum}

The study was performed in 2015-2016 at the Agricultural research center of Ardabil Province, Moghan $\left(39.39^{\circ} \mathrm{N}, 48.88^{\circ} \mathrm{E}\right)$ in the Northwestern part of Iran. The mean annual precipitation and temperature at the station are $332 \mathrm{~mm}$ and $21.5^{\circ} \mathrm{C}$, respectively. Fresh cow manure was obtained from the Cow Unit in cow development department in Animal Breeding and Animal Husbandry, Moghan. It was kept in $30 \mathrm{~L}$ 
containers at ambient temperature until fed to the reactors. Corn straw residue was collected from Corn Farm in Agriculture Research Centre of Ardabil, Iran and was chopped on site. The precision-chop CSR had an average size of 1-2 cm and was stored in ambient temperature. The inoculum used in the current reactors originated from an existing demonstration digester at Materials and Energy Research Center, Karaj, Iran in which the gas potential of different mixtures of pretreated cattle manure was evaluated. The digested material from the earlier experiment was pooled in a container and maintained anaerobically for one week at $35^{\circ} \mathrm{C}$ before being used as inoculum in the CSTR system. The characteristics of fresh cow manure, corn straw residue and inoculum are given in Table 1.

Table 1

Characteristics of inoculum, cow manure and corn straw residue

\begin{tabular}{lccc}
\hline Parameters & Inoculum & Cow manure & Corn straw \\
\hline TS(\%) & $7.11(\% \mathrm{FM})$ & $\begin{array}{c}(\% \mathrm{FM}) \\
16.21\end{array}$ & 90.4 \\
VS(\%) & $5.50(\% \mathrm{TS})$ & $\begin{array}{c}(\% \mathrm{FM}) \\
13.48\end{array}$ & 88.3 \\
VS: TS(\%) & 77.38 & 83.41 & 97.67 \\
pH & 7.08 & 7.49 & N.D \\
EC (ms/cm) & 17.05 & 9.81 & N.D \\
TC (\%) & $37.15(\% \mathrm{TS})$ & $32.40(\% \mathrm{TS})$ & 43.90 \\
TN(\%) & $1.74(\% \mathrm{TS})$ & $1.98(\% \mathrm{TS})$ & 0.63 \\
C/ N & 21.35 & 16.36 & 69.68
\end{tabular}

TS: total solid, VS: volatile solids, TC: Total carbon; TN: total nitrogen, FM: Fresh matter, DM: Dry matter; and ND: Not determined

\subsection{Experimental setup and operation}

A CSTR pilot-scale digester was designed with the purposes of ease of transportation of the digester to the site and automatic operation and control. The digester tank was cylindrical in shape with $110 \mathrm{~cm}$ height and 46 $\mathrm{cm}$ diameter, made from $4 \mathrm{~mm}$ thickness galvanized steel sheet. Its capacity was 180 l, with 140 L working volume as shown in Fig.1. The system can be divided into four sectors: control panel, feeding system, digester and agitation system and gas metering device. The digester was fitted with an adequate top plate, which supported the mixer, mixer motor (electrical threephase $380 \mathrm{~V}$ machine coupled with 15:1 gearbox), gas measurement and sampler. Sampling valves were located at relevant positions for gas and digester contents. The feeding system is at the top of the reactor. It has one outlet at the bottom for effluent discharge. Other tools and devices were used for biogas measurement and storage system consists of biogas piping, a biogas flow meter (displacement water), a biogas bag (tube), jackets, thermometer, $\mathrm{pH}$ sensor with conductivity measuring probe, circulating substrate through the reactor by mechanical stirrer (two propellers) ,control-bar and timer for timing the operation. The experiment was operated in semicontinuous mode with daily feeding. Semi-continuous anaerobic digestion of cow slurry and corn straw residue was investigated in mesophilic condition $\left(35^{\circ} \mathrm{C} \pm 2\right)$ with three different organic loading rates (OLR) of $1.4,2$ and $2.75 \mathrm{~kg} \mathrm{VS} /\left(\mathrm{m}^{3} . \mathrm{d}\right)$ for constant retention time of 25 days.

The experiment was run at mesophilic condition $\left(35^{\circ} \mathrm{C} \pm 2\right)$ using cow manure and corn straw residue in pilot-scale of AD and HRT equal to 25 days. This was done by placing a mixture of substrates in a floating drum container that was run with respect to two different cow manure (CM) to corn straw residue (CSR) mixing ratios of 100:0,75:25 and 50:50, to the semicontinuously fed tank reactor which employed with two different organic loading rates (OLR) of 2 and $3 \mathrm{~kg}$ VS. $\left(\mathrm{m}^{-3} \cdot \mathrm{d}^{-1}\right)$, respectively. Retention time of 25 days was maintained by feeding $5.6 \mathrm{~L}$ of substrate and removing $5.6 \mathrm{~L}$ of effluent daily and mixed slowly for $15 \mathrm{~min}$ every 45 minutes at a speed of about $100 \mathrm{rpm}$ according to Adebayo et al, (2015). The CSTR digester was filled with 60 liters of seed sludge (inoculum) for startup and addition of substrate was started with 80 liters using only cow slurry at $2 \mathrm{~kg} \mathrm{VS}$. $\left(\mathrm{m}^{-3} \cdot \mathrm{d}^{-1}\right)$ OLR.

The start-up period lasted one week and normal operation of the reactor continued afterwards on one daily feeding, 7 days a week, at a defined OLR and retention time of 25 days. Thus, $5600 \mathrm{~mL}$ of freshly prepared substrate mixture was added to digester and then an equivalent volume was discharged, so to maintain the volume inside the reactor constant.

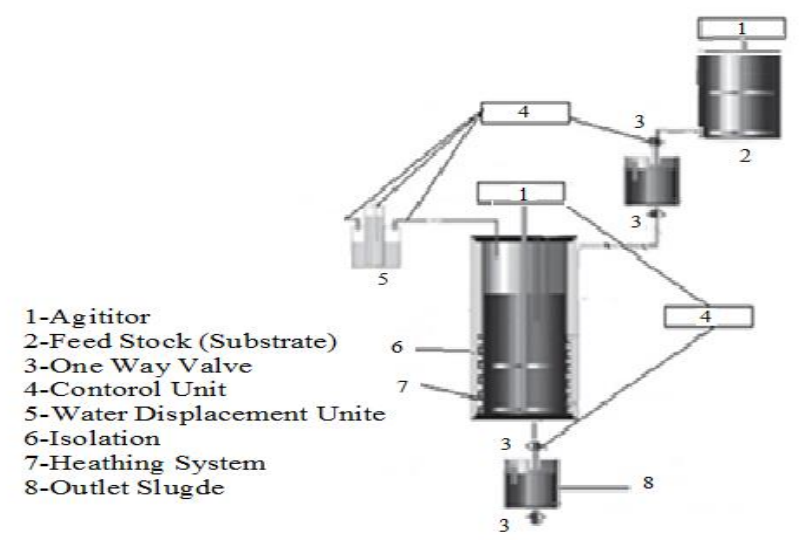

Figure 1. Schematic of digine semi- continues digester and elements 
Citation: Taghinazhad. J., Abdi, R. and Adl, M. (2017). Kinetic and Enhancement of Biogas Production for the purpose of renewable fuel generation by Co-digestion of Cow Manure and Corn Straw in a Pilot Scale CSTR System. Int Journal of Renewable Energy Development, 6(1),39-44, doi.org/10.14710/ijred.6.1.39-44 $\mathrm{P}$ a g e $\mid 40$

To evaluate the effects of co-digestion, the experimental run $\mathrm{C}$ was fed with a mixture of $75 \% \mathrm{CM}$ and 25\% CSR (VS-basis) quantity and the substrate mixture was diluted with water to achieve an initial OLR of $2 \mathrm{~kg} \mathrm{VS}\left(\mathrm{m}^{-1} \cdot \mathrm{d}^{-1}\right)$. Experimental run D was used to the same mixture as run $C$ but with $\mathrm{OLR}=3 \mathrm{~kg} \mathrm{VS} .\left(\mathrm{m}^{-1} \cdot \mathrm{d}^{-1}\right)$ and run $\mathrm{E}$ and $\mathrm{F}$ were fed with a mixture of $50 \% \mathrm{CM}$ and $50 \%$ CSR (VS-basis) quantity. The substrate mixture was diluted with water to achieve an initial OLR of 2 and $3 \mathrm{~kg} \mathrm{VS}\left(\mathrm{m}^{-1} \cdot \mathrm{d}^{-1}\right)$, whereas run $A$ and $B$ were fed solely with cow manure at 2 and $3 \mathrm{~kg}$ VS. $\left(\mathrm{m}^{-1} \cdot \mathrm{d}^{-1}\right)$ OLR respectively. The details of feeding scheme are given in Table 2.

Table 2

Feeding schemes for the four runs

\begin{tabular}{rrrrr}
\hline & \multicolumn{2}{c}{ Feedstock mixture } & & \\
\cline { 2 - 3 } Run & $\begin{array}{c}\text { Cow } \\
\text { manure } \\
\text { (\% VS) }\end{array}$ & $\begin{array}{r}\text { Corn straw } \\
\text { (\% VS) }\end{array}$ & $\begin{array}{c}\text { C/N of } \\
\text { feedstock }\end{array}$ & $\begin{array}{c}\text { OLR kg } \\
\text { VS.(m-1.d }\end{array}$ \\
\hline A & 100 & 0 & 16.35 & 2 \\
B & 100 & 0 & 15.81 & 3 \\
C & 75 & 25 & 22.07 & 2 \\
D & 75 & 25 & 21.61 & 3 \\
E & 50 & 50 & 26.34 & 2 \\
F & 50 & 50 & 27.11 & 3 \\
\hline
\end{tabular}

\subsection{Basic process parameters and analytical methods}

The volume of biogas was recorded by water displacement method in daily. The volume of the biogas was normalized to standard temperature and pressure. The biogas vented from the biogas piping was collected in a biogas bag for two week, all the biogas was transferred into gas chromatograph for measuring the composition of biogas ( $\mathrm{CH}_{4}$ and $\mathrm{CO}_{2}$ ) ( $\mathrm{Li}$ et al., 2014). The analytical methods for total solids (TS), volatile solids (VS), pH and EC was analyzed according to the APHA standard methods and Total nitrogen (TN) estimated by the Kjeldahl method (APHA, 1998).

\subsection{Methane production simulation}

Cumulative methane production from the AD of the substrates was simulated using Gompertz equation, Exponential rise to maximum and Logistic equation. In addition, specific cumulative biogas or methane production was simulated using modified logistic kinetic model, exponential rise to maximum and modified Gompertz kinetic model. Exponential rise to maximum equation shown in Eq. (1) based on (Bilgili et al., 2009; Zwieterring, et al., 1990; Lo, et al., 2010)

$$
Y=P(1-\exp (-k t))
$$

Where $\mathrm{Y}$ is the cumulative methane yield $\left(\mathrm{L} . \mathrm{kg}^{-1}\right), \mathrm{P}$ is the ultimate potential of biogas or methane production $\left(\mathrm{L} \mathrm{kg}^{-1}\right)$, $\mathrm{t}$ is time (day) in all digestion period and $\mathrm{k}$ is the first order kinetic constant $\left(\mathrm{d}^{-1}\right)$.

The lag phase $(\lambda)$ can be calculated with the modified Logistic and Gompertz model as described by Zwietering et al. 1990, as follows: The modified equation for simulation is a form of the Logistic equation which is generally applied to simulate the cumulative biogas or methane production is presented in Eq. (2) (Zwieterring, et al., 1990).

$$
Y=P\left\{1-\exp \left[4 r_{m} P^{-1}(\lambda-t)+2\right]\right\}
$$

For the modified Gompertz kinetic model equation is a form of the Gompertz model which is generally applied to simulate the cumulative biogas or methane production as follow Eq. (3) (Zwieterring, et al., 1990; Lo, et al., 2010 ; Maamri \& Amrani, 2014; Latinwo \& Agarry, 2015).

$$
Y=P \exp \left\{-\exp \left\lfloor r_{m} P^{-1} e(\lambda-t)+1\right]\right\}
$$

Where $\mathrm{Y}, \mathrm{t}$ and $\mathrm{P}$ are the same as aforementioned, $\mathrm{r}_{\mathrm{m}}$ is the maximal biogas production rate $\left(\mathrm{L} \mathrm{kg}^{-1} \mathrm{~d}^{-1}\right)$ while $\lambda$ is the lag phase (day) and e is equal to 2.718282. All regression equations were completed by MATLAB11b version.

\section{Results and Discussion}

\subsection{Biogas and methane production}

Daily biogas production rate and cumulative biogas volume from single digestion of cow manure (experimental runs A and B) and co-digestion of CM and CSR (runs C, D, E and F) are presented in Fig.2 and Fig.3. It could be seen from Fig. 2 that run A (single digestion of $\mathrm{CM}$ at OLR= 2) and run D (75\% CM + 25\% CSR (VS basis) with OLR=3) showed the lowest and highest daily biogas production respectively.

The digestion runs started the generation of biogas on the $2^{\text {nd }}, 2^{\text {nd }}, 3^{\text {rd }}, 4^{\text {rd }}, 4^{\text {nd }}$ and $3^{\text {rd }}$ day of feeding start, respectively. This observation indicates that biogas production started early for runs $\mathrm{A}$ and $\mathrm{B}$ and thus a reduction in start-up time as compared to codigestions. However, the delays in biogas production may probably be due to two factors. First, the types of feeding that have been given to the cows, which are mainly agricultural crops, such as corn straw residue. Generally, about $90 \%$ of the dry weight of most plant materials is due to cellulose, hemicellulose and lignin. The existence of lignin in lignocelluloses makes a protective barrier that stops plant cell destruction by microorganisms for conversion to energy (methane content) unless of course pretreated (Avicenna, etal., 
2015). Different pretreatment methods can improve the physical and chemical structure within the lignocellulosic biomass and facilitates hydrolysis rates for conversion to biogas. Second, it might be as a result of volatile fatty acids (VFAs) accumulation due to the low biodegradability of cow manure, which resulted in partial inhibition in the digester. When the VFAs were consumed, the partial inhibition was overcome and biogas production started (Angelidaki, \& Ahring, 1993; Avicenna et al 2015) As biogas started its generation, the results demonstrate high biogas production rates for the initial days. Another probable description for this outcome is that most of the exposed cellulose and hemicelluloses content of the substrate was degraded which make it accessible to the microorganisms for conversion to biogas.

In this study, the maximum cumulative biogas yield at day 42 was 997, 1168, 1311 and $1429 \mathrm{~L}$ for runs A to $D$, respectively. The biogas yields from co-digestion of $\mathrm{CM}$ and CS were significantly higher than that of single digestion of CM in both OLRs. The daily biogas rates were 7.33 and $6.39 \mathrm{~L} / \mathrm{kg}$ VS at steady state (1535) days for single CM and 10.32 and $8.16 \mathrm{~L} / \mathrm{kg}$ VS at and 8.46 and $7.15 \mathrm{~L} / \mathrm{kg}$ VS for co-digestion of CSR/CM (50:50), in steady state (15-35) days for co-digestion of $\mathrm{CS} / \mathrm{CM}$, corresponding to OLRs equal to 2 and $3 \mathrm{kgVS}$. $\left(\mathrm{m}^{-3} \cdot \mathrm{d}^{-1}\right)$, respectively (Figure 2$)$.

Comino et al. also outstanding the effect of anaerobic co-digestion during the fermentation process of agricultural wastes. They stated the interests of optimizing the ratio of crops and organic loading rate(OLR) in co-digestion of cattle manure with energy crops by the fact that during feeding within 70\% VS of crop in the feedstock, up to $109 \%$ higher specific methane yield was achieved than during the start-up run of single manure digestion (Comino et al., 2013). It was also found that biogas production from cattle manure or animal wastes increases by co-digesting with crop residues like wheat straw, sugarcane stalks, maize stalks, rice straw, cotton stalks, oil palm and onion waste fronds (Somayaji \& Khanna, 1994; Sharma, 2002; Karellas et al., 2010; Tong et al., 2013; SanaeiMoghadam et al., 2014; Zhang, et al., 2014).

The observed phenomenon could be attributed to additional nutrients availability (feedstock composition) and improved carbon-to-nitrogen ratio (C: N) provided by the corn straw residue. Similar observations have also been reported by Tong et al (2013), Sanaei- Moghadam et al (2014) and Latinwo \& Agarry (2015). Both organic loading rates on codigestion of CM and CSR gave better methane yields than single digestion of cow manure (Table 3). The reactor showed average biogas production efficiency was obtained $0.242,0.204,0.311,0.296,259.5$ and $235 \mathrm{~m}^{3}$. $\left(\mathrm{kg} \mathrm{VS}\right.$ input) ${ }^{-1}$ for 2 and $3 \mathrm{~kg} \mathrm{VS} .\left(\mathrm{m}^{-3} \cdot \mathrm{d}^{-1}\right)$ at CM to CSR mixing ratios of 100:0, 75:25 and 50:50, respectively.

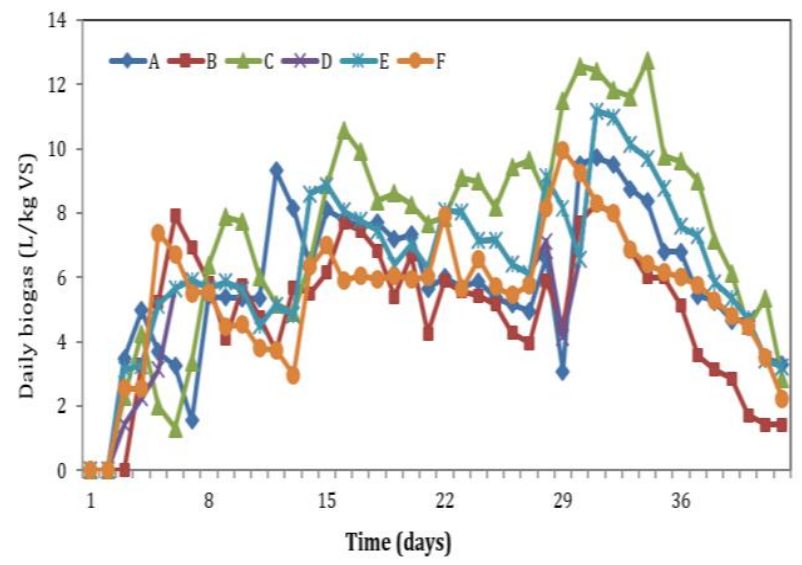

Fig. 2 The daily production rates of biogas in different runs

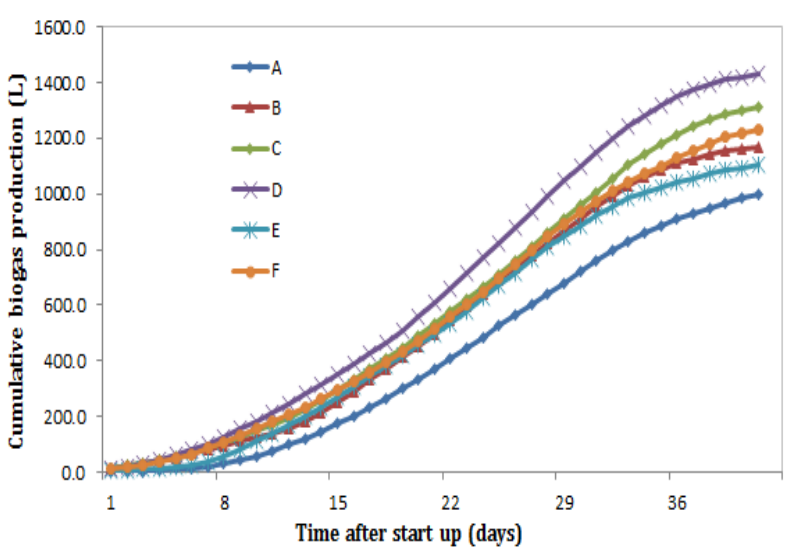

Figure 3 The cumulative biogas yields of OLR and different ratio of cow manure and co-digested with corn straw residue in different runs

In addition, VS reduction upon stable performance as $64.57,54.96,74.11,62.76,64.11$ and $58.30 \%$ during the runs $A$ to $F$, respectively. On the other hand, this study suggests that co-digestion (in runs $\mathrm{C}$ to $\mathrm{F}$ ) can improve the efficiency of biogas production by about $25 \%$ comparing single digestion of cow manure (runs A and B). However, the cumulative biogas production started to decrease after $32^{\text {th }}$ day in all digesters. The reactor showed stable performance with approvable methane content 54-63 percent (Table 3).

Table 3

Operational conditions for the varies runs

\begin{tabular}{|c|c|c|c|}
\hline Run & $\begin{array}{c}\text { Average } \\
\text { methane } \\
\text { Content }(\%)\end{array}$ & $\begin{array}{c}\text { Max. specific } \\
\text { methane yield } \\
(\mathrm{mL} \mathrm{g-1})^{a}\end{array}$ & $\begin{array}{c}\text { Average VS } \\
\text { reduction (\%) }\end{array}$ \\
\hline A & 61.17 & 148.03 & 64.57 \\
\hline B & 62.58 & 127.66 & 54.96 \\
\hline C & 57.87 & 179.97 & 74.11 \\
\hline D & 54.8 & 156.28 & 62.76 \\
\hline $\mathrm{E}$ & 55.66 & 147.05 & 64.11 \\
\hline $\mathrm{F}$ & 55.75 & 131.22 & 58.30 \\
\hline
\end{tabular}

a Based on weekly average production 
Citation: Taghinazhad. J., Abdi, R. and Adl, M. (2017). Kinetic and Enhancement of Biogas Production for the purpose of renewable fuel generation by Co-digestion of Cow Manure and Corn Straw in a Pilot Scale CSTR System. Int Journal of Renewable Energy Development, 6(1),39-44, doi.org/10.14710/ijred.6.1.39-44

$\mathrm{P}$ a g e $\mid 42$

\section{2 pH profiles}

In anaerobic fermentation, the bacteria of methanogenic are more sensitive than bacteria of hydrolytic and acidogenic to environmental conditions. At ambient temperature, the $\mathrm{pH}$ is the one of the most influential parameters that affects anaerobic digestion process (Rabah et al., 2010). For instance, the pH of reactor liquid effluent showed the process stability and its variety also depends on the buffering capacity of the system (Mata-Alvarez et al 2000). Furthermore, it was observed that $\mathrm{pH}$ of the fermentation slurry was slightly dropped with increase in OLR upon single digestion of cow manure while it was maintained pretty constant against OLR increase at co-digestion runs as shown in Table 3

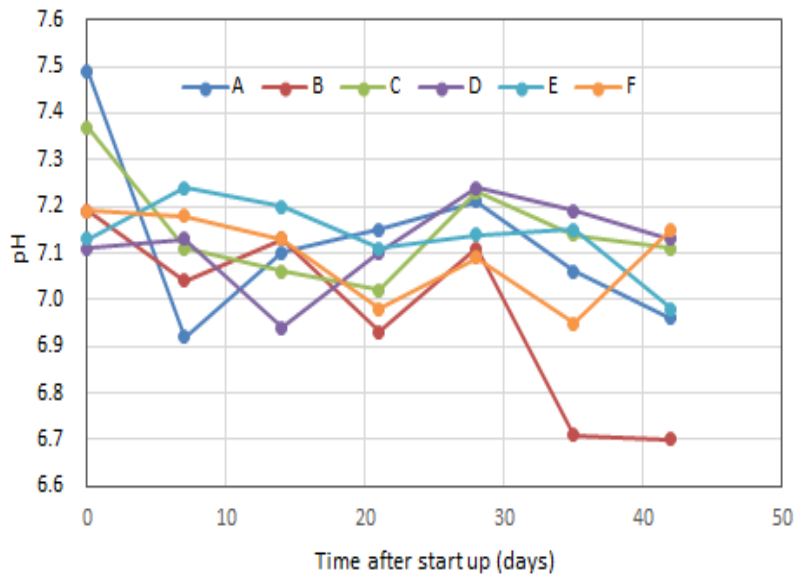

Fig. 4. $\mathrm{pH}$ variations of digester content during the different runs

Table 4.

Comparison of values of model constants, RMSE and coefficient of determination $\left(\mathrm{R}^{2}\right)$ obtained from kinetic models fitted to specific cumulative biogas production data in varies runs

\begin{tabular}{|c|c|c|c|c|c|c|c|}
\hline Kinetics models & Coefficient and parameters & $\mathbf{A}$ & B & C & D & $\mathbf{E}$ & $\mathbf{F}$ \\
\hline \multirow[t]{4}{*}{ Modified Logistic } & $\mathrm{R}^{2}$ & 0.990 & 0.9895 & 0.9954 & 0.9924 & 09942 & $5^{0.990}$ \\
\hline & RMSE & 6.120 & 6.912 & 6.997 & 8.139 & 6.108 & 7.146 \\
\hline & $\mathrm{P}\left(\mathrm{Nl} .(\mathrm{kg} \mathrm{VS})^{-1}\right.$ & 263.1 & 223.2 & 360.4 & 345.8 & 275.9 & 273.4 \\
\hline & $\mathrm{r}_{\mathrm{m}}(\mathrm{Nl} \text {.(kg VS. day) })^{-1}$ & 8.271 & 6.664 & 10.53 & 8.981 & 8.246 & 7.021 \\
\hline \multirow[t]{5}{*}{$\begin{array}{c}\text { Modified } \\
\text { Gompertz }\end{array}$} & $\mathrm{R}^{2}$ & 0.9960 & 0.9941 & 0.998 & 0.9956 & 0.9973 & $5^{0.994}$ \\
\hline & RMSE & 5.141 & 5.150 & 4.603 & 6.201 & 4.245 & 5.47 \\
\hline & $\mathrm{P}\left(\mathrm{Nl} .(\mathrm{kg} \mathrm{VS})^{-1}\right.$ & 319.9 & 266.1 & 482.5 & 450.5 & 337.8 & 352.4 \\
\hline & $\mathrm{r}_{\mathrm{m}}(\mathrm{Nl}$.(kg VS. day)-1 & 7.62 & 6.185 & 9.628 & 8.318 & 7.584 & 6.52 \\
\hline & $\lambda$ (day) & 6.696 & 4.085 & 7.458 & 4.012 & 4.59 & 3.637 \\
\hline
\end{tabular}

correlation coefficient

Figure 4 shows a relative decrease in the $\mathrm{pH}$ of the fermenting medium in the first week of anaerobic digestion in runs $\mathrm{A}, \mathrm{B}$ and $\mathrm{C}$ however, the $\mathrm{pH}$ values fluctuated in the acceptable range except for run $\mathrm{B}$ that $\mathrm{pH}$ dropped to 6.7 after $30^{\text {th }}$ day. The $\mathrm{pH}$ of the digester content remained steady state and showed lower fluctuations with regards to variation in OLR indicating that the digestion in reactor was well buffered and maintained in the suitable range for the methanogenesis. Enhancements of biogas yield due to increment of $\mathrm{pH}$ probably the result of addition metabolic activity of the microbial community that is exist in the digester (Lyberator \& Skiades, 1999). It has been reported that anaerobic bacteria required a natural environment and thus a $\mathrm{pH}$ ranging from 6.4 to 7.2 is needed for optimum biogas production (Rabah et al 2010).

\subsection{Kinetic model of biogas production}

Kinetic parameters of fermentation process are always useful in comprehension inhibitory mechanisms of bio decomposition and are applied to analyses the efficiency of reactors and design the appropriate reactors (Li et al., 2014). Fig. 5(a), 5(b), 5(c), 5(d), 5(e) and 5(f) demonstrate the biogas accumulation simulation, using Modified Gompertz and Logistic kinetic plots along with observed values of specific cumulative biogas production data from single digestion of $\mathrm{CM}$ and co-digested $\mathrm{CM}+\mathrm{CSR}$ for OLRs of 2 and $3 \mathrm{~kg}$ VS. $\left(\mathrm{m}^{-3} \cdot \mathrm{d}^{-1}\right)$,respectively. The Modified Gompertz and Logistic kinetic plot had the highest correlation and lower RMSE for simulating biogas accumulation.

The coefficient of determination $\left(\mathrm{R}^{2}\right)$ obtained as 0.9960, 0.9941, 0.998, 0.9956, 0.9973 and 0.9945 using modified Gompertz kinetic model and (0.990, 0.9995, 
$0.9954,0.9924,0.9942$ and 0.9905 ) by applying Logistic kinetic model for runs A, B, C, D, E, and F, as shown in Table 4, respectively. Therefore, both the modified Gompertz and logistic kinetic model could be used to simulate methane production by a completely stirred tank reactor (CSTR) under semi-continuous feeding circumstance.

In the Logistic kinetic equation, the kinetic rate constant was found to be in the order of biogas production (263.1, 223.2, 360.4, 345.8, 275.9 and 373.4)
LN. kg VS ${ }^{-1}$ input at 42 th day for runs A, B, C , D, E and F respectively. The maximal biogas production rate $r_{m}$ and lag phase period $(\lambda)$ was found to be presented in table 4. Thus, in modified Gompertz equation, the potential of biogas production (P) was found to be in the order of specific normal biogas production at (319.9, 266.1, 482.5, 450.5, 337.8 and 352.4) LN. kg VS-1 input at day 42 for runs A, B, C , D, E and F respectively. Biogas production rate $\left(r_{m}\right)$ and lag phase period $(\lambda)$ was found to be presented in Table 4 .
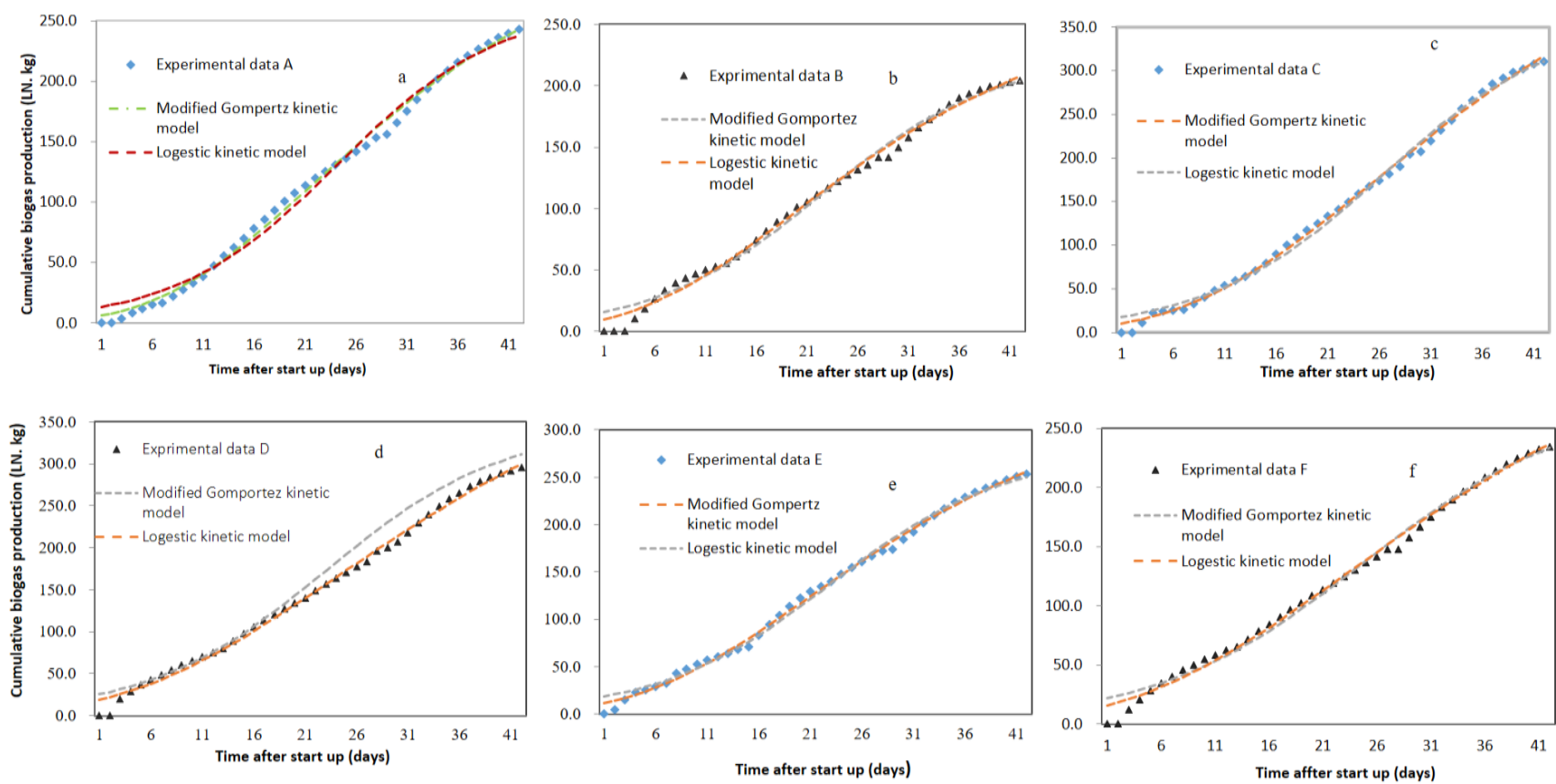

Figure 5. Kinetic growth models of modified Gompertz and logistic equations fitted to the specific cumulative methane production data in different runs(a) only CM with OLR=2, (b) only CM with OLR =3, (c) $75 \% \mathrm{CM}+25 \%$ CSR with OLR=2, (d) $75 \% \mathrm{CM}+25 \% \mathrm{CSR}$ with OLR=3, (e) $50 \%$ CM + $50 \%$ CSR with OLR=2 and (f) $50 \%$ CM + 50\% CSR with OLR=3

\section{Conclusion}

The anaerobic CSTR which was employed under semi-continuous feeding circumstance during this study demonstrated an acceptable performance along both single digestion of cow manure and Co-digestion of cow manure with corn straw residue although co-digestion experimental runs showed better results in terms of $\mathrm{pH}$ stability and specific methane production. The methane content (54-63\%) and VS reduction of around 55-74\% in different runs represented promising process efficiency under the practical conditions of anaerobic digestion operations. In addition, Modified Gompertz and Logistic kinetic modeling plots had higher correlation than exponential rise to maximum plot for simulating biogas production.

Therefore, with increasing the environmental concerns and predominant wastes management crises, optimizing biogas production is effective way to reduce GHG emissions in terms of the of generation renewable energy by co-digestion of agricultural and animal waste.

\section{References}

Adebayo, A. O., Jekayinfa, S. O. \& Linke, B. (2015) Effects of Organic Loading Rate on Biogas Yield in a Continuously Stirred Tank Reactor Experiment at mesophilic temperature, British Journal of Applied Science \& Technology. 11(4): 1-9.

Altas, L. (2009) Inhibitory effect of heavy metals on methaneproducing anaerobic granular sludge, J. Hazard. Mater. 162, 1551-1556.

Angelidaki, I., \& Ahring, B.K. (1993) Thermophilic digestion of livestock waste: the effect of ammonia. Applied Microbiology Biotechnology, 38: 560-564.

APHA (American Public Health Association), (1998) Standard methods for the Experimental of Water and Wastewater, APHA Washington, D.C.

Avicenna., Mel, M., Ihsan, S. I., \& R. H. Setyobudi, (2015). Process Improvement of Biogas Production from Anaerobic Co-digestion of Cow Dung and Corn Husk. Procedia Chemistry, 14:91-100

Bilgili, M.S., Demir, A. \& Varank, G. (2009) Evaluation and modeling of biochemical methane potential (BMP) of landfilled solid waste: a pilot scale study, Bioresource Technology. 100: 4976-4980.

Boe, K., \& Batstone,D.J. (2005) Optimization of serial CSTR biogas reactors using modeling by ADM1", In: Proceedings of the First International Workshop on the IWA Anaerobic Digestion Model No. 1 (ADM1), 2-4 September 2005, Lyngby,Denmark, pp. 219221. 
Boe, K. ( 2006) Online monitoring and control of the biogas process", Ph.D. Thesis. Technical University of Denmark. $221 \mathrm{p}$.

Comino,E., Rosso, M. \& Riggio,V.( 2013) Investigating of increasing organic loading rate in the co-digestion of energy crops and cow manure mix", Bioresource Technology, 101: 3013-3019.

Deublein, D., \& Steinhauser, A. (2011) Biogas from waste and renewable resources, an introduction: John Wiley \& Sons.

Estevez, M.M., Linjordet,,R. \& Morken, J. (2012) Effects of steam explosion and co-digestion in the methane production from Salix by mesophilic batch assays, Bioresource Technology. 104:749-756

Hartmann, H., Angelidaki, I., \& Ahring, B. (2003) Co-digestion of the organic fraction of municipal waste with other waste types, Biomethanization Organic Fraction Municipal Solid Wastes.181199.

Jagadabhi, P., Lehtomäki, A. \& Rintala, J. (2008) Co-digestion of grass silage and cow manure in a CSTR by re-circulation of alkali treated solids of the digested, Environ. Technol. 29: 1085-1093.

Karellas, S., Boukis, I., Kontopoulos, G. (2010) Development of an investment decision tool for biogas production from agricultural waste. Renewable and Sustainable Energy Reviews, 14(4): 12731282

Karimi, K., Shafiei, M. \& Kumar, R. (2013) Progress in physical and chemical pretreatment of lignocelluloses biomass, In: Gupta VK, Tuohy MG, editors. Biofuel technologies. Berlin Heidelberg: Springer, pp. 53-96.

Latinwo, G.K., \& Agarry, S.E. (2015) Modeling the kinetics of biogas from mesophilic anaerobic co-digestion of cow dung with plantain peels. Int. Journal of Renewable Energy Development 4(1): 55-63.

Li, Y., Zhang, R., He. Y., Zhang. Ch., Liu, X., Chen, Ch. \& Liu G., (2014)Anaerobic co-digestion of chicken manure and corn Stover in batch and continuously stirred tank reactor (CSTR), Bioresource Technology. 156: 342-347.

Lichtman, RJ. (1983) Biogas systems in India. Arlington, USA: Volunteers in Technical Assistance (VITA) in cooperation with the Committee on Science and Technology for Developing Countries (COSTED)

Lo, H.M., Kurniawan, T.A, Sillanpaa, M.E.T, Pai, Y.Y., \& Chiang, C.F. (2010) Modeling biogas production from organic fraction of MSW co-digested with MSWI ashes in anaerobic bioreactors. Bioresources Technology, 101:6329-6335.

Lyberator G., \& Skiades, I.V. (1999) Modeling of anaerobic digestion A Review", Global Nest. 1: 63 -76.

Maamri, S., \& Amrani, M. (2014) Biogas Production from Waste Activated Sludge Using Cattle Dung Inoculums- Effect of Total Solid Contents and Kinetics Study. Ene. Procedia. 50: 352-359.

Mata-Alvarez, J., Mace, S. \& Llabres, P. (2000) Anaerobic digestion of organic solid wastes, An overview of research achievement and perspectives, Bioresource Technology. 74: 3-16.

Mattocks, R. (1984) Understanding biogas generation, Technical Paper, No. 4.Volunteers in Technical Assistance, Virginia, USA,. p. 13.

Oliveira, LS., \& Franca, AS. (2009) From solid bio wastes to liquid biofuels", In: Ashworth GS, Azevedo P, editors. Agricultural wastes. New York: Nova Science Publisher.

Omer, T.O., \& Fedalla M.O. (2002). Engineering design and Economic Evaluation of a family - sized biogas project in Nigeria. Technovation

Pesta, G. (2007) Anaerobic digestion of organic residues and wastes, In: Oreopoulou V, Russ W, editors. Utilization of by-products and treatment of waste in the food industry. New York: Springer; pp. 53-72.

Rabah, A. B., Baki, A. S., Hassan, L. G., Musa, M., \& Ibrehim, A. D. (2010) Production of biogas using abattoir waste at different time. Science World Journal, 5, 4

Ray, N.H.S., Mohanty, M.K. \& Mohanty, R.C. (2016) Biogas Compression and Storage System for Cooking Applications in Rural Households, international journal of renewable energy research. 6(2).

Sanaei- Moghadam, A., Abbaspour-Fard, M.H., Agahel,H.., Aghkhan M.H. \& Abedini-Torghbeh, J. (2014) Enhancement of Biogas Production by Co-digestion of Potato Pulp with Cow Manure in a CSTR System. Appl. Biochem. Biotechnol., 173: 1858-1869.
Sharma, D.K., (2002) Studies on availability and utilization of onion storage waste in a rural habitat. Ph.D. Thesis, Centre for Rural Development and Technology, Indian Institute of Technology, Delhi, India.

Somayaji, D., \& Khanna, S. (1994) Biomethanation of rice and wheat straw. World Journal of Microbiology and Biotechnology, 10: 521523

Song Z, G., Yang, Y., Guo \& Zhang,T. (2012) Comparison of tow chemical pretreatments of rice straw for biogas production by anaerobic digestion. Bio Resources, 7: 3223-3236.

Taricska, JR., Long, DA., Chen, JP., Hung, YT. \& Zou, SW. (2009) Anaerobic Digestion", In: Wang LK, Pereira NC, Hung YT, editors. "Biological treatment processes", Hand book of environmental engineering. New York: Humana Press Springer Science, pp.589634.

Themelis, N.J., \& Ulloa,P.A. (2007) Methane generation in landfills. Renewable Energy.32 (7), 1243-1257.

Tong, Zh., Linlin, L. Zilin,S., Guangxin, R., Youyang,F., Xinhui, H. \& Gaphe, Y. (2013) Biogas production by co-digestion of Gout Manure anaerobic with three crop residues. Plos. ONE, 8(6): e66845.

Umar, H. S, Firdausi, B. R, Sharifah, R. W. A, \& Fadimtu, M. (2013) Biogas production through Co-digestion of palm oil mill effluent with cow manure. Nigerian Journal of Basic and Applied Science, 21(1): 79-84

Wang, J. \& Wan, W. (2009) Kinetic models for fermentative hydrogen production", a review. Int. J. Hydrogen Energy. 34, 3313-3323.

Wilkie, A.C., \& Evans, J. M. (2010) Aquatic plants: an opportunity feedstock in the age of bioenergy, Biofuels. 1, 311-321.

Zhang, R., \& Zhang, Z. (1999) Bio gasification of rice straw with an anaerobic phased solids digester system, Bioresource Technology. 68: $235-245$

Zhang, T., Yang, Y., Liu, L., Han, Ren ,Y. G. \& Yang, G. (2014) Improved biogas production from chicken manure anaerobic digestion using cereal residues as co substrates. Energy \& Fuels.pubs.acs.org.

Zhu, B., Zhang, P., Lord, R.J., Jenkins, B. \& Li, X. (2009) Characteristics and biogas production potential of municipal solid waste pretreated with a rotary drum reactor. Bio resource Technology 100:1122-1129.

Zwietering, M.H., Jongernburger, I., M.Rombouts, F. \& VantsRiet, K. (1990) Modeling of the bacterial growth curve", Applied and Environmental Microbiology. 56,1875-1881. 